\title{
Orman üçgülü (Bituminaria bituminosa C.H. Stirt) bitkisinde bazı özelliklerin mevsimsel değişiminin belirlenmesi*
}

\author{
Elif TUZEN ŞAHIN ${ }^{\circledR}$ 1, Zeki ACAR ${ }^{\circledR}$, Mehmet CAN ${ }^{\circledR 1}$, ilknur AYAN ${ }^{\circledR 1}$
}

10ndokuz Mayıs Üniversitesi Ziraat Fakültesi Tarla Bitkileri Bölümü, Samsun

*Bu çalışma OMÜ BAP tarafından PYO.ZRT.1904.15.009 proje numarası ile desteklenmiştir. Bazı veriler Elif Tuzen Şahin'in Yüksek Lisans Tezinden alınmıștır.

Alınış tarihi: 3 Eylül 2019, Kabul tarihi: 12 Aralık 2019

Sorumlu yazar: Mehmet CAN, e-posta: zir.mehmet@gmail.com

\section{$\ddot{0 ̈ z}$}

$\mathrm{Bu}$ araştırma, Samsun, Sinop ve Kastamonu illerinden toplanmış olan 85 orman üçgülü 'OÜ' (Bituminaria bituminosa) genotipi arasından seçilen 42 genotip ile 2015 yılında yürütülmüștür. Seçilen genotiplerde 4 farklı dönemde (15 Ocak, 15 Nisan, 15 Temmuz ve 15 Kasım) bazı morfolojik (bitki boyu, yaprakçık eni, yaprakçık boyu) ve tarımsal (kuru otta ham protein, ADF, NDF ve bazı mineral madde içerikleri) özellikler belirlenmiştir. Değişik ekolojik özellik gösteren yerlerden toplanan oÜ genotiplerinin Ocak, Nisan, Temmuz ve Kasım dönemlerindeki ortalama bitki boyları sırasıyla $13.48 \mathrm{~cm}, 17.39 \mathrm{~cm}, 93.06 \mathrm{~cm}$ ve $10.40 \mathrm{~cm}$ olmuştur. Yapılan çalışmada Ocak, Nisan, Temmuz ve Kasım dönemlerinde genotiplerin ortalama ham protein oranları sirasıyla \%22.62, 26.59, 24.57 ve 24.40 ; ADF oranları \%19.19, 18.02, 18.42 ve 18.41; NDF oranları $\% 34.40,28.71,27.74$ ve 29.59 olarak tespit edilmiştir. OÜ genotiplerinin Ocak, Nisan, Temmuz ve Kasım dönemlerinde sırasıyla ortalama kalsiyum oranları \%2.05, 1.88, 1.94 ve 2.02; magnezyum oranları $\% 0.41,0.38,0.60$ ve 0.44 ; fosfor oranları \% $0.31,0.40,0.41$ ve 0.35 ; potasyum oranları $\% 1.94$ $2.63,2.35$ ve $2.30 ; \mathrm{Ca} / \mathrm{P}$ oranları $6.85,4.72,4.76$ ve 5.88 ; $\mathrm{K} / \mathrm{Ca}+\mathrm{Mg}$ oranları ise $0.80,1.17,0.94$ ve 0.95 olarak tespit edilmiştir. Bazı genotiplerin yıl boyunca büyümesini sürdürdüğü ve yeşilliğini koruduğu, yaprak ve taze sürgünlerde yem kalitesinin çok yüksek olduğu tespit edilmiştir. Sulama ve gübreleme yapılmadığı ve hiçbir hastalık ve zararlısının gözlenmediği dikkate alındığında, uygun çeşitler geliştirildiği zaman, sulanamayan, düşük verimli alanlarda mera ve yem bitkisi olarak yetiştirilme potansiyelinin çok yüksek olduğu sonucuna varılmıștır.

Anahtar kelimeler: Orman Üçgülü, morfolojik özellikler, kalite, besin içeriği, mevsimsel değişim

\section{Determination of Seasonal Variation of Some Traits at Tedera (Bituminaria bituminosa C. $\mathrm{H}$. Stirt)}

\begin{abstract}
This study was carried out with $42 B b$ genotypes which were selected over 85 genotypes collected from Samsun, Sinop and Kastamonu provinces in 2015. At four different seasons (15 th of January, April, July and November) some traits such as; plant height, leaflet width and length, crude protein, ADF, NDF and mineral contents of hay were determined for all genotypes. Average plant heights of genotypes were 13.48, 17.39, 93.06 and $10.40 \mathrm{~cm}$ at January, April, July and November, respectively. Average crude protein ratios were 22.62, 26.59, 24.57 and 24.40\%; ADF ratios were 19.19, 18.02, 18.42 and 18.41\%; NDF ratios were 34.40, 28.71, 27.74 and $29.59 \%$, respectively at the same periods. Some mineral contents of $B b$ genotypes were, also, determined at January, April, July and November. These values were 2.05, 1.88, 1.94 and $2.02 \%$ for Calcium; 0.31, 0.40, 0.41 and $0.35 \%$ for Phosphorus, $0.41,0.38,0.60$ and $0.44 \%$ for Magnesium; 1.94 ,
\end{abstract}


2.63, 2.35 and $2.30 \%$ for Potassium, respectively. While average $\mathrm{Ca} / \mathrm{P}$ rates of the genotypes were $6.85,4.72,4.76$ and $5.88 ; \mathrm{K} /(\mathrm{Ca}+\mathrm{Mg})$ rates were determined as $0.80,1.17,0.94$ and 0.95 at the same periods. Some genotypes were found to maintain growth and foliage throughout the year, and feed quality was very high in leaves and fresh shoots. Considering that irrigation and fertilization was not performed and no diseases and pests were observed, it was concluded that when suitable varieties were developed, the potential for growing as pasture and forage plants in non-irrigable, low-yielding areas was very high.

Key words: Bituminaria bituminosa, morphological traits, quality, nutrients, seasonal variation

\section{Giriş}

Türkiye, geniş bir kesimine düşen yıllık 400 mm'nin altındaki yağış miktarıyla yarı-kurak iklimin etkisi altında iken, diğer taraftan da küresel ısınmadan en fazla etkilenecek ülkeler arasında yer almaktadır. Küresel ısınma tehdidi birçok ürünün yetişmesini kısıtlayacağından, zaten zor durumda olan tarım sektörü bir başka darboğaza girecektir (Uğur, 2008). Dolayısıyla, değişen şartlara uyum sağlayabilecek yeni çeşitlerin geliştirilmesine yönelik çalışmalar yoğunlaştırılmalıdır. Türkiye çayır ve meralarının vejetasyonu büyük oranda serin mevsim yem bitkilerinden oluşmaktadır. $\mathrm{Bu}$ bitkiler haziranağustos döneminde yüksek sıcaklık ve kuraklıktan dolayı ya tamamen kurumakta, ya da uyku dönemine girmektedir. $\mathrm{Bu}$ nedenle, yaz döneminde çayır meraların verimi oldukça düşmektedir. Diğer türlerin kuruduğu ve ot kalitesinin düștüğü bu dönemde, Orman üçgülü "OÜ” (Bituminaria bituminosa) yeşil kalmakta ve meraların verimini ve besin değerini artırmaktadır. Ayrıca, bitki uyum sağladığı ılıman bölgelerde yıl boyunca gelişmesini sürdürdüğü için, sürekli yeşil yem sağlama özelliğin de göstermektedir (Gutman ve ark., 2000). OÜ, kuraklık ve sıcaklığa son derece dayanıklı olması, yaz ayları boyunca büyümesini sürdürebilmesi ve yeşilliğini koruması, marjinal alan olarak tanımlanan eğimli, taşlık, üst toprak tabakasını kaybetmiş ve derinliği az olan topraklarda sulanmadan yetiştirilebilmesi nedeniyle üzerinde en çok durulan bitkilerden birisidir. Nitekim İspanya, İsrail ve Avusturalya ulusal OÜ araştırma programları geliştirmişlerdir (Gintzburger ve Le Houerou, 2002; Sternberg ve ark., 2006; Real ve ark., 2008; Fernandez ve ark., 2010; Real ve ark., 2014). Ülkemiz bu türün en önemli doğal yayılma alanlarından birisini oluşturmasına karşın, yem bitkisi veya kurak meralarda kullanımına yönelik çalışmalar yeni başlamıştır. Oysa, ülkemizle benzer özellikler taşıyan İspanya, İtalya, İsrail, bazı Kuzey Afrika ülkelerinde son yıllarda çalışmaların yoğunlaştığı görülmektedir. Avustralya'da ise Akdeniz ülkelerinden getirtilen genotiplerle, ülkenin sıcak ve kurak bölgelerine uygun çeşitler geliştirmek amacıyla ulusal bir program kapsamında yoğun araştırmalar yürütülmektedir.

Yapılan çalıșmalar oÜ bitkilerinde gelişme, verim, besin maddesi içeriği gibi özelliklerin mevsimlere, gelişme dönemlerine ve çevre koşullarına göre değişebildiğini göstermiștir. OÜ bitkisinin kuru otunda protein içeriğinin \%10.3 ile \%20.4, ADF içeriğinin \%23.8 ile \%41.9, NDF içeriğinin \%38 ile $\% 56.3$ arasında ve sindirilebilme oranının da \%46 ile \%51 arasında değiştiği belirlenmiştir (Ventura ve ark., 1999, 2004, 2009; Alvarez ve ark., 2004; Sternberg ve ark., 2006; Pecetti ve ark., 2007; FAO, 2010). Samsun'da yürütülen çeşitli çalışmalarda bitkinin ham protein oranının gelişme devresi ve bitkinin kısımlarına göre \%7.0-25.6 arasında değiştiği, ham kül oranının \%9.5, yaprak oranının \%59.9-78.5, ADF oranının \%19.8-47.1, NDF oranının \%27.4-56.4, göreceli yem değerinin (RFV) \%86-250 arasında değiştiği saptanmıştır (Acar ve ark., 2001; Gulumser ve ark., 2010; Kumbasar, 2015; Acar ve ark., 2016a ve b). Orta Karadeniz Bölgesi'nden toplanan çok sayıda genotiple çalışan Kumbasar (2015), bitkinin gelişme devrelerine göre kalsiyum oranının \%1.28-1.87, magnezyum oranının \%0.360.40 , fosfor oranının $\% 0.18-0.42, \mathrm{Ca} / \mathrm{P}$ oranının \%3.1-7.98, K/(Ca+Mg) oranının \% $0.29-1.70$ ve potasyum oranının \%0.51-2.75 arasında değiștiğini belirtmiştir. Ventura ve ark. (2004), OÜ bitkilerinde farklı gelişme dönemlerine ait mineral madde içeriklerini inceledikleri bir çalışmada, Ca içeriğinin \%0.86-1.13, P içeriğinin \%0.25-0.32, Mg içeriğinin $\% 0.18-0.26$, Na içeriğinin \%0.22-0.30 ve K içeriğinin ise $\% 0.26$ ile 0.33 arasında değiștiğini belirlemişlerdir.

Bitkilerde bulunan mineral elementlerin bir kısmı mutlak gerekli olduğu halde bir bölümü yararlı, bazıları ise zararlı olabilmektedir. Mera bitkileri büyüme dönemleri süresince sürekli aynı miktarda mineral elemente sahip olmazlar. Genellikle büyüme başlangıcında yüksek mineral içeriğine sahip bitkilerde, gelişmelerinin ilerlemesi ile artan organik 
kütleye bağlı olarak mineral kapsamlarında azalma meydana gelir (Underwood ve Suttle, 1999).

Hayvanların beslenmesi için yemlerde gerekli olan elementlerin belirli sınırlar içerisinde olması gerekmektedir. Nitekim bu elementlerin eksikliği ya da fazlalığı çeşitli hastalıklara sebep olmaktadır. Tajeda ve ark. (1985), geviş getiren hayvanlar için yemlerde en az \%0.3 Ca, \%0.2 $\mathrm{Mg}$ ve \%0.8 $\mathrm{K}$ bulunması gerektiğini bildirirken, Kidambi ve ark. (1989), organizmalarda vücut fonksiyonlarında görev alan minerallerden Fe'in \%0.21, K'un \%0.65, Ca'un \%0.31 ve Mg'un \%0.10 oranında bulunması gerektiğini belirtmektedirler.

Amerika Yem Bitkileri ve Mera Komisyonu kaba yemleri ADF ve NDF içeriklerine göre kalite sınıfına ayırmışlardır. Buna göre, ADF içeriği \%31-35 arasında olan kaba yemler çok iyi, \%36-40 arasında olanlar iyi, \%41-42 arasında olanlar orta, \%43-45 arasında olanlar kötü kalite sınıfına dahil edilmektedirler. NDF açısından ise; \%41-46 arasında olanlar çok iyi, \%47-53 arasında olanlar iyi, \%54-60 arasında olanlar orta, \%61-65 arasında olanlar kötü olarak değerlendirilmektedir (AFGC, 2009).

$\mathrm{Bu}$ çalışma, Orta Karadeniz Bölgesi'nden toplanmış 42 orman üçgülü genotipinin bazı kalite özelliklerini ve mevsimsel besin içerikleri değişimini belirlemek üzere 2015 yllında yürütülmüştür.

\section{Materyal ve Yöntem}

$\mathrm{Bu}$ araştırma 2015 yılında Ondokuz Mayıs Üniversitesi Ziraat Fakültesi Uygulama ve Araştırma arazisinde yürütülmüștür. Çalıșmanın yürütüldüğü araziden alınan toprak örneklerinin analizi sonucunda, deneme alanının killi yapıda, hafif asit karakterde, kireçsiz, tuzsuz ve organik madde miktarının az olduğu belirlenmiștir. Deneme alanının uzun yıllar yağış toplamı $706 \mathrm{~mm}$ ve ortalama sıcaklık $14.5{ }^{\circ} \mathrm{C}$ 'dir. 2015 yılında düșen toplam yağıș miktarı $779.5 \mathrm{~mm}$ ve ortalama sıcaklık $15.50{ }^{\circ} \mathrm{C}$ olarak gerçekleşmiştir.

Çalışmada bitki materyali olarak, Orta Karadeniz Bölgesi'nden daha önceden toplanmış 85 genotip içerisinden yem kalitesi ve verim açısından üstün olduğu belirlenen 42 orman üçgülü genotipi kullanılmıştır. Denemede herhangi bir gübreleme ve sulama işlemi yapılmamıştır. Gelişme dönemi boyunca herhangi bir hastalı etmeni veya zararlı etkisi gözlenmemiștir. Özellikle fide devresinde yabancı otlar elle yolunarak temizlenmiștir. Tarlada bitkiler 2015 yllı boyunca incelenerek Uluslararası Bitki Gen Kaynakları Araştırma Enstitüsü'nün
(IPGRI, 1990) esasları temelinde, çok yıllık baklagil yem bitkileri için belirtilen karakterizasyon kriterlerine göre bitki boyu, yaprakçık eni, yaprakçık boyu ölçülmüş; ham protein oranı, mineral madde $(\mathrm{K}, \mathrm{Ca}, \mathrm{P}, \mathrm{Mg}), \quad \mathrm{ADF}$ ve NDF analizleri gerçekleştirilmiştir. Bitki boyu her genotip için her parselde 10 bitkide, yaprakçık eni ve boyu değerleri ise 5 bitkide ortada yer alan 5 yaprakta orta yaprakçıkta ölçülerek ortalamaları alınmıştır. Temmuz ayında yapılan ölçüm ve gözlemlerden sonra bitkiler biçilmiş ve Kasım ayındaki ölçüm ve gözlemler yeniden büyüyen bitkilerde yapılmıştır. Kimyasal analizlerin tümü bitkilerin yaprak ve taze sürgünlerinin ögütülmesiyle elde edilen materyalde gerçekleștirilmiştir (Gövdenin sertleşen alt bölümleri hayvanlar tarafından tercih edilmemektedir). Kimyasal analizlerin tümü Near Infrared Reflectance Spectroscopy (NIRS) (Foss 6500) cihaziyla IC-0904FE paket programı kullanılarak gerçekleştirilmiştir. Elde edilen veriler Tesadüf Parselleri Deneme Desenine göre analiz edilmiştir. Aralarında farklılık bulunan ortalamalar için Duncan testi uygulanmış ve gruplandırmalar 0.05 olasılık düzeyine göre yapılarak harflendirilmiştir.

\section{Bulgular ve Tartışma}

Bitki boyu yönünden dönemler arası farklılık önemli ( $\mathrm{p} \leq 0.05)$ bulunmuştur. 2015 yılı Ocak döneminde genotiplerin ortalama bitki boyu $13.48 \mathrm{~cm}$, Nisan döneminde $17.39 \mathrm{~cm}$, Temmuz döneminde $93.06 \mathrm{~cm}$ ve Kasım döneminde $10.40 \mathrm{~cm}$ olarak ölçülmüştür (Çizelge 1). Dört dönem birlikte değerlendirildiğinde, en uzun bitki boyu Temmuz döneminde 56 numaralı genotipde $(152.0 \mathrm{~cm})$, en kısa ise Kasım döneminde 26 numaralı genotipde $(7.33 \mathrm{~cm})$ tespit edilmiştir. Genotiplerin kendilerine özgü bitki boyu değerlerine ulaştıkları Temmuz dönemindeki ölçümler göz önüne alındığında, genotiplerin bitki boyu değerleri $44.33 \mathrm{~cm}$ (28 numaralı genotip) ile 152.00 (56 numaralı genotip) arasında değişmiştir. Bu farklılık genotiplerin genetik yapıları ve uyum sağladıkları ekolojik koşulların farklı olmasından kaynaklanmaktadır. Gulumser ve ark. (2010), OÜ genotiplerinde bitki boyunun genotiplere göre önemli değişkenlik gösterdiğini ve çiçeklenme döneminde 47.0 ile $105.6 \mathrm{~cm}$ arasında değiştiğini belirlemiştir. Acar ve ark. (2016a), 25 OÜ genotipi ile yürüttükleri çalıșmada, bitki boyunun gelișme devresi ve genotiplere göre değiștiğini, gelişme devresi ilerledikçe bitki boyunun artarak çiçeklenme döneminde ortalama 116.4 cm'ye ulaştığını 
saptamışlardır. Acar ve ark. (2016b), OÜ genotiplerinin toplandıkları yükselti ile bitki boyu, biçim sayısı ve verim arasında çok önemli ilişki olduğunu, yüksek rakımlara uyum sağlayan genotiplerin sonbahardan itibaren uyku devresine girdikleri, ilkbaharda geç büyümeye başladıkları, dolayısıyla bitki boyu, biçim sayısı ve verimlerinin daha düşük olduğunu belirlemişlerdir. Nitekim, en düşük bitki boyu değerinin ölçüldüğü 28 numaralı genotip Karadeniz ve kuzeyden esen rüzgarlara açık sırt bir alandan $420 \mathrm{~m}$ rakımdan toplanırken, en uzun boylu olan 56 numaralı genotip SamsunBağkur'dan $4 \mathrm{~m}$ rakımdan korunaklı bir alandan toplanmiştır.

Çizelge 1. Genotiplerin, dönemlere göre, bazı morfolojik özellikleri ve kimyasal içerikleri*

\begin{tabular}{|c|c|c|c|c|}
\hline \multirow[t]{2}{*}{ Özellik } & \multicolumn{4}{|c|}{ Dönemler } \\
\hline & Ocak & Nisan & Temmuz & Kasım \\
\hline Bitki boyu $(\mathrm{cm})$ & $13.48 \mathrm{c}$ & $17.39 \mathrm{~b}$ & $93.06 \mathrm{a}$ & $10.40 \mathrm{c}$ \\
\hline Değișim genişliği & $9.67-24.00$ & $12.33-32.00$ & $44.33-152.00$ & $7.33-19.00$ \\
\hline Yaprakçık eni (mm) & $26.71 \mathrm{~b}$ & $30.95 \mathrm{a}$ & $20.23 \mathrm{~d}$ & $24.45 c$ \\
\hline Değişim genişliği & 19.11-40.38 & $22.78-45.71$ & $12.68-24.24$ & 17.11-38.05 \\
\hline Yaprakçık boyu (mm) & $29.88 \mathrm{c}$ & $34.40 \mathrm{~b}$ & $45.77 \mathrm{a}$ & $27.05 \mathrm{~d}$ \\
\hline Değişim genişliği & $17.51-46.21$ & $22.84-52.21$ & $37.28-55.46$ & $17.51-44.21$ \\
\hline HP oranı (\%) & $22.62 \mathrm{c}$ & $26.59 \mathrm{a}$ & $24.57 \mathrm{~b}$ & $24.40 \mathrm{~b}$ \\
\hline Değişim genişliği & $19.09-25.24$ & 23.44-29.59 & $21.36-28.27$ & 20.64-29.23 \\
\hline $\mathrm{ADF}(\%)$ & $19.19 \mathrm{a}$ & $18.02 \mathrm{~b}$ & $18.42 \mathrm{~b}$ & $18.41 \mathrm{~b}$ \\
\hline Değişim genişliği & $15.94-25.07$ & $15.07-20.44$ & $15.99-21.46$ & $15.20-22.29$ \\
\hline NDF $(\%)$ & $31.40 \mathrm{a}$ & $28.71 \mathrm{c}$ & $27.74 \mathrm{~d}$ & $29.59 \mathrm{~b}$ \\
\hline Değișim genișliği & $27.46-38.96$ & $26.08-32.66$ & $22.88-31.13$ & $26.47-35.12$ \\
\hline
\end{tabular}

*Aynı sırada aynı harflerle gösterilen ortalama değerler arasında 0.05(p $\leq 0.05)$ olasılık düzeyinde farklılık yoktur.

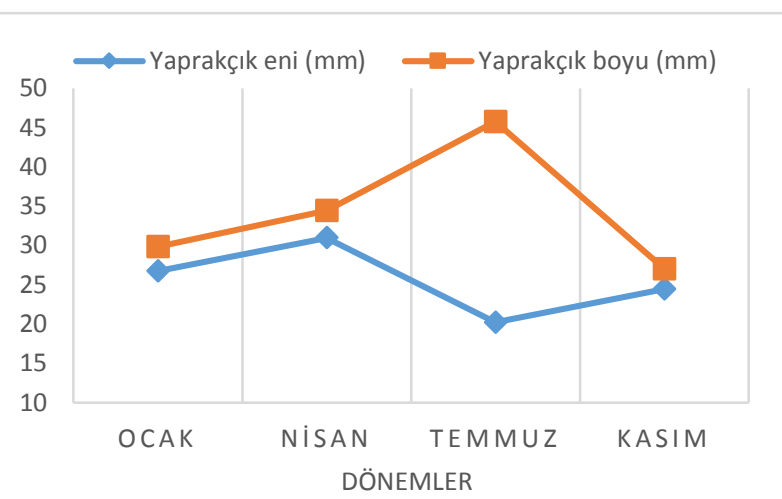

Şekil 1. OÜ genotiplerinde yaprakçık eni ve boyu değerlerinin mevsimsel değişimi

OÜ genotiplerinin ortalaması olarak değerlendirildiğinde ortalama bitki boyu değerleri, Ocak döneminden başlayarak Temmuz dönemine kadar artmıştır. Temmuzda hasat edilen bitkiler, Kasım ortasına kadar sınırlı bir büyüme göstermişlerdir. Kasım dönemi ile Nisan dönemi arasında artış hızı çok yavaş seyretmiș, NisanTemmuz arasında çok hızlı artarak en yüksek noktaya çlkmıştır. Her ne kadar kuraklığa ve yüksek sıcaklara toleranslı olsa da, OÜ bir serin iklim baklagil bitkisi olup, C3 fotosentez yoluna sahiptir. $\mathrm{Bu}$ nedenle yazın artan sicaklıklar ve kuraklık bitkide büyümeyi sınırlandırmaktadır. Nitekim Kuzey Yarım Kürede ve suptropik iklim kuşağında yer alan ülkemizde, serin iklim baklagillerin büyümesi için en uygun iklim koşulları ilkbahar ve yaz bașlangıcı döneminde oluşmaktadır.

Yaprakçlk eni ve boyu yönünden gelişme dönemleri arasındaki farklılık önemli $(\mathrm{p}<0.05)$ bulunmuştur. En büyük yaprakçık eni değerleri Nisan döneminde ölçülürken (ortalama 30.95 mm), diğer dönemlerde yaprakçık eni değerlerinin azaldığı ve ortalama değerin Ocak, Kasım ve Temmuz dönemlerinde sırasıly 26.71, 24.45 ve $20.23 \mathrm{~mm}$ olduğu saptanmıştır (Çizelge 1 ve Şekil 1). Nisan döneminde daha belirgin olmak üzere, yaprakçık eni değerleri 
yönünden genotipler arasında önemli değişkenliklerin olduğu gözlenmiştir. Yaprakçık eni değerlerinin en üst seviyeye ulaştı̆̆ Nisan ayında en yüksek değer $45.71 \mathrm{~mm}$ ile 29 numaralı genotip de ölçülürken, en düşük değer 22.78 mm ile 14 numaralı genotip de tespit edilmiştir.

Ocak ayından başlayarak ortalama yaprakçık boyu değerleri sürekli artarak Temmuz ayında en yüksek noktaya ulaşmış, ardından keskin bir şekilde azalarak Kasım ayında en düşük seviyeye inmiştir (Çizelge 1 ve Şekil 1). Yaprakçık boyu yönünden genotipler arasında önemli değişkenliklerin olduğu gözlenmiştir. Değerlerin en üst düzeye ulaştığı Temmuz ayında, genotiplerin ortalama yaprakçık boyu değerlerinin 56.06 (49 numaralı genotip) ile 37.28 (28 numaralı genotip) $\mathrm{mm}$ arasında değiştiği tespit edilmiştir.
Genotipler arasındaki farklılık büyük ölçüde genetik yapı farklılığından kaynaklanmaktadır. Nitekim, Kumbasar (2015), OÜ genotiplerinde gelişme devresinin ilerlemesine paralel olarak yaprakçık eni değerlerinin azaldığını, büyüme başlangıcı devresinde ortalama $40.94 \mathrm{~mm}$ olan yaprakçık eninin, sürekli azalarak tohum bağlama döneminde 16.89 mm'ye indiğini belirlemiștir. Gülümser (2011), ise OÜ genotiplerinin ilk biçimlerinde ortalama yaprakçık boyunun $45 \mathrm{~mm}$ olduğunu, ikinci biçimde ise bu değerin 35 mm'ye düştüğünü bildirmiştir. Benzer şekilde, Kumbasar (2015), OÜ genotiplerinde yaprakçık boyu değerlerinin çiçeklenme dönemine kadar artarak 55.07 mm'ye ulaştığını, sonra yeniden azalarak tohum bağlama devresinde 42.65 mm'ye indiğini saptamıştır.

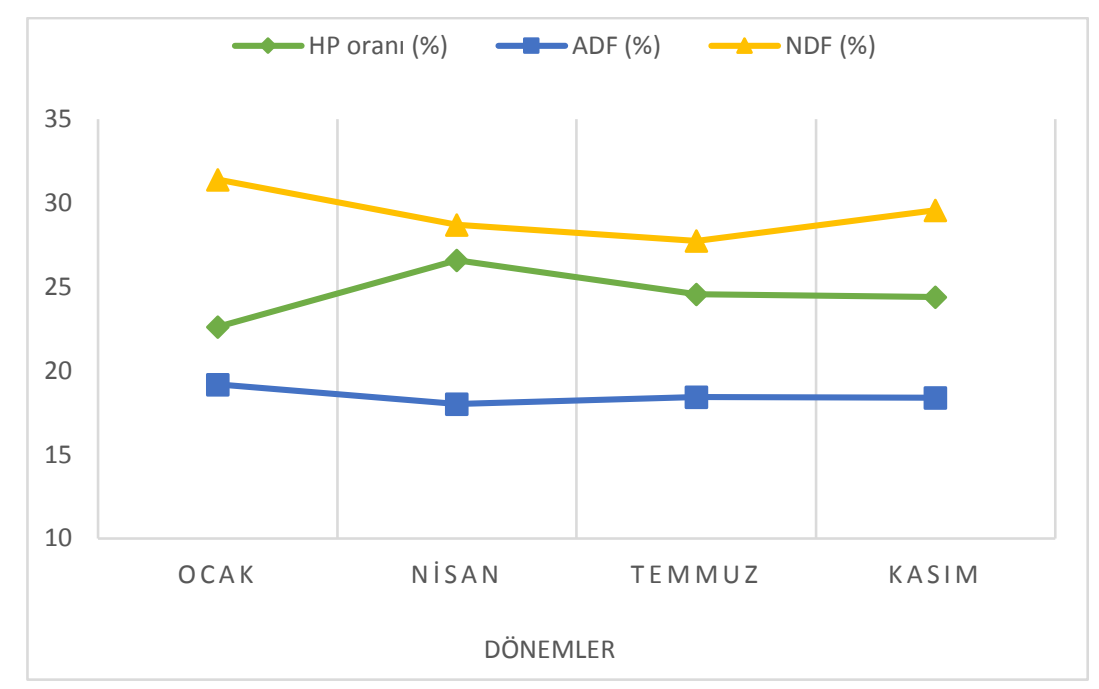

Şekil 2. OÜ genotiplerinde mevsimlere göre HP, ADF ve NDF değişimi

Genotiplerin ortalaması olarak ham protein oranı yönünden dönemler arasında önemli farklılık saptanmıștır. En yüksek ham protein oranı ortalama olarak \%26.59 ile Nisan döneminde, en düşük ham protein oranı ise ortalama $\% 22.62$ ile Ocak döneminde tespit edilmiştir. Temmuz ve Kasım dönemleri arasında istatistiksel açıdan anlamlı bir farklılık bulunmamıştır. OÜ genotiplerinde Nisan ayında en yüksek düzeye çıkan ham protein oranı daha sonra azalmaya başlamış, ancak yaz ve sonbahar döneminde aynı seviyede seyrettikten sonra, kış aylarında yeniden azalmıștır (Çizelge 1 ve Şekil 2). Yapraklardaki ham protein oranının en üst seviyeye çıktığı Nisan döneminde en yüksek oran 65 (\%29.70), en düşük ise A1 (\%23.44) genotiplerinde tespit edilmiştir. Protein oranı yönünden dönemler arasında görülen farklılı bitkilerin fizyolojik özellikleri ve metabolik aktivitelerinin (fotosentez hızı, solunum hızl vb.) mevsimlere göre önemli değişkenlik göstermesinden kaynaklanmaktadır. Ayrıca bitkilerin protein oranı olgunluğa bağlı olarak azaldığı gibi bitki organları arasında da farklılıklar bulunmaktadır (Önal Așcl ve Acar, 2018). Nisan dönemi bitkinin sahip olduğu genç doku ve organ miktarının en yüksek olduğu dönemde iken Temmuz ayında otun içinde yaşlı yapraklar ve gövde yer almıştır. Bu nedenle Temmuz ayında belirlenen ham protein oranı Nisan dönemine göre daha düșük olmuştur. Nitekim, Ventura ve ark. (2004), OÜ'de ham protein oranının mevsimlere göre önemli değişkenlik gösterdiğini, ilkbahar ve sonbaharda belirlenen değerlerin diğer mevsimlerden daha yüksek olduğunu bildirmiştir. Genotipler arasında görülen değişkenlik, genetik yapı farklılığı ve değișik 
yerlerden toplanan bitkilerin deneme koşullarına uyum yönünden gösterdikleri tepkinin farklı olmasından kaynaklanmaktadır. Elde edilen sonuçlar, OÜ genotiplerinde ham protein oranının genotiplere ve bitkinin farklı kısımlarına göre değiştiğini bildiren Gülümser (2011), ve Kumbasar (2015), ile bitki gelişme dönemlerine göre oü genotiplerinde ham protein oranının çok önemli düzeyde değiștiğini belirleyen Kumbasar (2015),'in bulguları ile uyumludur. Ayrıca, yapılan farklı çalışmalarda OÜ bitkilerinde protein oranının \%15.9-20.3 arasında değiștiği tespit edilmiştir (Ventura ve ark., 1999. 2004; Acar ve ark., 2001; FAO, 2010).

ADF ve NDF oranı yönünden genotiplerin ortalaması olarak mevsimsel dönemler arasında çok önemli farklılık belirlenmiştir. En yüksek ADF oranı ortalama \%19.19 ile Ocak döneminde tespit edilirken, diğer dönemler arasında istatistiksel yönden anlamlı bir farklılığın olmadığı saptanmıştır. En düşük NDF oranı ortalama \%27.74 ile Temmuz döneminde, en yüksek ise $\% 31.40$ ile Ocak döneminde belirlenmiștir. NDF oranı Temmuz ayından sonra sonbahar ve kış aylarında artmış, ilkbaharda ise yeniden azalmıştır (Çizelge 1 ve Şekil 2). Kış aylarında bitkilerin gelişmesi çok yavaşladığı için genellikle yeni yaprak oluşturmazlar. Mevcut yapraklar yaşlandıkça yapısında selüloz oranı artmaktadır. Genotipler arasındaki değişkenlik tümüyle bitkilerin genetik yapısı ve denemenin yürütüldüğü koşullara gösterdikleri uyum ve tepkiyle ilişkilidir. Nitekim, ADF ve NDF oranının genotiplere (Gülümser, 2011; Kumbasar, 2015) ve mevsimlere (Ventura ve ark., 2004) göre değişkenlik gösterdiği, bitkide gelişme devresi ilerledikçe arttığ (Kumbasar, 2015) tespit edilmiştir. ADF sindirilebilirliği ifade etmektedir ve yemlerde \%30 oranının üzerinde olmaması istenmektedir (Yavuz ve ark., 2009). NDF oranı bitkinin gelişmişlik veya olgunluğunun bir göstergesi olarak kullanılmaktadır. Yemlerde NDF oranının \%40 veya bu oranın altında olması istenmektedir (Yavuz ve ark., 2009). OÜ genotiplerinin tümünde her mevsimde yaprakların ADF ve NDF oranı yem kalitesini olumsuz yönde etkileyecek seviyenin altında bulunmuştur.

OÜ genotiplerinde Ca içeriği yönünden dönemler arasındaki farklılık önemli bulunmuştur. Bu özellik yönünden iki ayrı istatistiksel grup oluşmuş, Ocak ve Kasım dönemleri ilk, Temmuz ve Nisan dönemleri ise ikinci grupta yer almışlardır. Yaprakların kalsiyum içeriğinde kış mevsiminden ilkbahar mevsimine doğru belirgin bir düşüş meydana gelmiş ve ilkbahardan sonra tekrardan önemli derecede artmış ve sonbahar döneminde neredeyse kış mevsimindeki orana yaklaşmıştır (Çizelge 2).

Çizelge 2. Genotiplerin, dönemlere göre, mineral madde içerikleri*

\begin{tabular}{|c|c|c|c|c|}
\hline \multirow[t]{2}{*}{ Özellik } & \multicolumn{4}{|c|}{ Dönemler } \\
\hline & Ocak & Nisan & Temmuz & Kasım \\
\hline Сa (\%) & $2.05 \mathrm{a}$ & $1.88 \mathrm{~b}$ & $1.94 \mathrm{~b}$ & $2.02 \mathrm{a}$ \\
\hline Değișim genişliği & $1.59-2.35$ & $1.64-2.02$ & $1.68-2.53$ & $1.64-2.35$ \\
\hline $\mathrm{K}(\%)$ & $1.94 \mathrm{c}$ & $2.63 \mathrm{a}$ & $2.35 \mathrm{~b}$ & $2.30 \mathrm{~b}$ \\
\hline Değișim genişliği & $1.40-2.56$ & $2.33-3.03$ & $1.96-2.73$ & $1.54-3.60$ \\
\hline $\operatorname{Mg}(\%)$ & $0.41 \mathrm{c}$ & $0.38 \mathrm{~d}$ & $0.60 \mathrm{a}$ & $0.44 \mathrm{~b}$ \\
\hline Değişim genişliği & $0.34-0.51$ & $0.33-0.42$ & $0.51-0.84$ & $0.37-0.54$ \\
\hline $\mathrm{P}(\%)$ & $0.31 \mathrm{~d}$ & $0.40 \mathrm{~b}$ & $0.41 \mathrm{a}$ & $0.35 \mathrm{c}$ \\
\hline Değișim genişliği & $0.24-0.36$ & $0.33-0.46$ & $0.33-0.47$ & $0.28-0.51$ \\
\hline $\mathrm{K} /(\mathrm{Ca}+\mathrm{Mg})$ & $0.80 \mathrm{c}$ & $1.17 \mathrm{a}$ & $0.94 \mathrm{~b}$ & $0.95 \mathrm{~b}$ \\
\hline Değişim genişliği & $0.52-1.25$ & $0.94-1.41$ & $0.66-1.18$ & $0.55-1.74$ \\
\hline $\mathrm{Ca} / \mathrm{P}$ & $6.85 \mathrm{a}$ & $4.72 \mathrm{c}$ & $4.76 \mathrm{c}$ & $5.88 \mathrm{~b}$ \\
\hline Değișim genișliği & $4.93-9.05$ & $3.81-6.09$ & $3.78-7.82$ & $3.20-8.13$ \\
\hline
\end{tabular}

*Aynı sırada aynı harflerle gösterilen ortalama değerler arasında 0.05(p $\leq 0.05)$ olasılık düzeyinde farklılık yoktur. 
İlkbahar döneminde Ca oranındaki azalmanın nedeni bu elementin hızla yeni oluşan dokulara yapı maddesi olarak taşınmasıdır. Kalsiyum bitkide yapı maddesidir. $\mathrm{Bu}$ nedenle hızlı büyüme devresinde bitki dokularında bulunan kalsiyumun bir kısmı yeni oluşan dokulara taşınmaktadır (Elinç, 2007). Gülümser (2011), ve Kumbasar (2015), OÜ genotiplerinde ilkbaharda Ca oranının azaldığını, bitki büyümesinin yavaşladığı yaz aylarından itibaren yeniden arttığını belirlemişlerdir. Geviş getiren hayvanlar için yemlerde en az \%0.3 oranında Ca bulunması gerektiği bildirilmiștir (Tejata ve ark., 1985; Kidambi ve ark., 1989). Bu açıdan değerlendirildiğinde tüm oÜ genotiplerinin Ca içerikleri yeterlidir.

OÜ genotiplerinin $\mathrm{K}$ içeriği yönünden dönemler arasındaki farklılığın önemli olduğu saptanmıştır. Farklı mevsimsel dönemlerdeki ortalama K oranı incelendiğinde, en yüksek oran Nisan döneminde (\%2.63), en düşük ise Ocak döneminde (\%1.94) tespit edilmiştir. Temmuz ve Kasım dönemleri arasında istatistiksel yönden anlamlı bir farklılık bulunmamıștır (Çizelge 2). K toprakta ve bitkide hareketliliği fazla ve lüks tüketime yatkın bir element olduğundan (Elinç, 2007), bitkilerin su ve besin maddesi alımının hızlı olduğu bahar aylarında, bitki dokularındaki $\mathrm{K}$ miktarı en üst seviyeye çıkmıştır. Ventura ve ark. (2004), yaptıkları çalışmada OÜ bitkilerinde potasyum oranının \%2.6 ile \% 3.3 arasında değiștiğini; Gulumser ve ark. (2010), K oranının OÜ genotiplerinin yapraklarında ortalama \%2.7 olduğunu tespit etmişlerdir. Kumbasar (2015), OÜ genotiplerinin yapraklarında $\mathrm{K}$ içeriğinin erken ilkbaharda bitkilerin hızlı büyüdüğü dönemde $\% 2.42$ ile en yüksek seviyeye çıktığını ve daha sonra yeniden azaldığını belirlemiştir.

Magnezyum oranı yönünden oÜ genotiplerinin ortalaması olarak farklı mevsimsel dönemler arasında önemli farklılık bulunmuştur. $\mathrm{Mg}$ oranı Temmuz döneminde en yüksek seviyeye (\%0.60) çıkmış, bu dönemden sonra sürekli azalarak Nisan döneminde en düşük (\%0.38) düzeye inmiştir (Çizelge 2). Bitkilerde yüksek düzeydeki $\mathrm{K}$ ve amonyum içeriği Mg alımını olumsuz etkilemektedir (Elinç, 2007). Çizelge 2 incelendiğinde, oü genotiplerinin $\mathrm{K}$ ve $\mathrm{Mg}$ içerikleri arasında ters yönlü bir ilişki olduğu görülmektedir. K seviyesinin en yüksek olduğu Nisan ayında Mg düzeyi en düşük düzeye inmiştir. Benzer şekilde Kumbasar (2015),' da OÜ genotiplerinde $\mathrm{Mg}$ içeriğinin erken büyüme dönemlerinde en düşük olduğunu (\%0.40) ve gelişme döneminin ilerlemesiyle arttı̆̆ını (Çiçeklenme döneminde \%0.57) tespit etmiştir. Gülümser (2011), OÜ genotiplerinin yapraklarında Mg oranının ortalama \% 0.56 olduğunu bildirmiştir. Yapılan araştırmalarda geviş getiren hayvanlar için yemlerde en az \%0.1 - 0.2 oranında Mg bulunması gerektiği bildirilmiştir (Tejata ve ark., 1985; Kidambi ve ark., 1989). OÜ genotiplerinin Mg içeriğinde hayvan besleme açısından herhangi bir eksiklik görülmemektedir.

P oranı açısından OÜ genotiplerinin ortalaması olarak dönemler arasında önemli farklılık olduğu tespit edilmiştir. P oranı Temmuz ayında en yüksek düzeye çıkarken (\%0.41), Kasım ve Ocak ayları boyunca azalmış ve sonra yeniden artmaya başlamıştır (Çizelge 2). P bitkide hareketli bir elementtir. Yeni oluşan sürgün ve yapraklara, yaşlı dokulardan P taşınmaktadır (Elinç, 2007). Yapılan bazı çalışmalarda OÜ genotiplerinin yapraklarında ortalama \%0.36-0.41 oranında P olduğu saptanmıștır (Gülümser, 2011; Kumbasar, 2015).

İncelenen mineral maddeler yönünden oÜ genotipleri arasında sınırlı düzeyde değişkenlikler olduğu gözlenmiştir. Bu değişkenlikler büyük ölçüde genotiplerin genetik yapılarının farklı olmasından kaynaklanmaktadır. Ayrıca, genotipler uyum sağladıkları koşullardan farklı özellikler gösteren bir alanda denemeye alınmışlardır. Yeni koşullara uyumları ve gösterdikleri tepkinin de aynı olmamasının, bu değişkenlikte etken olduğu düşünülmektedir.

OÜ genotiplerinde belirlenen $\mathrm{K} /(\mathrm{Ca}+\mathrm{Mg})$ oranı yönünden dönemler arasında önemli farklılık olduğu tespit edilmiştir. En yüksek $\mathrm{K} /(\mathrm{Ca}+\mathrm{Mg})$ oranı 1.17 olarak Nisan ayında saptanırken, bu oran sürekli azalarak Ocak'ta 0.80'e inmiștir. Temmuz ve Kasım ayları arasında önemli bir farklılık bulunmamıştır (Çizelge 2). Gülümser (2011) ve Kumbasar (2015) OÜ genotiplerinin yapraklarında $\mathrm{K} /(\mathrm{Ca}+\mathrm{Mg})$ oranının 2'nin altında olduğunu bildirmişlerdir. $\mathrm{K} /(\mathrm{Ca}+\mathrm{Mg})$ oranının geviş getiren hayvanlar için yemlerde 2.2'den küçük olması istenilmektedir (Korkmaz ve ark., 1993). Bu oran 2.2'nin üzerine çıktığında tetani riski artmaktadır (Ward, 1966). OÜ'ne ait tüm genotiplerin $\mathrm{K} /(\mathrm{Ca}+\mathrm{Mg})$ oranının bu değerin altında olduğu görülmektedir.

OÜ genotiplerinde belirlenen $\mathrm{Ca} / \mathrm{P}$ oranı yönünden dönemler arasında önemli farklılık olduğu tespit edilmiştir. Farklı mevsimsel dönemler incelendiğinde ortalama $\mathrm{Ca} / \mathrm{P}$ oranı en yüksek Ocak 
döneminde (6.85) belirlenirken, bunu Kasım (5.88) izlemiş, en düşük ise Nisan ve Temmuz dönemlerinde (sırasiyla 4.72 ve 4.76) tespit edilmiştir. Yapılan bazı çalışmalarda OÜ genotiplerinin yapraklarında $\mathrm{Ca} / \mathrm{P}$ oranının 3.1610.24 arasında (Gülümser, 2011; Kumbasar, 2015) değiştiği belirlenmiştir. OÜ bir baklagil olduğu için Ca yönünden zengindir. Yapraklarda Ca içeriğinin yüksekliği, doğal olarak Ca/P oranının artmasına yol açmıştır. Hayvan organizmasında Ca:P dengesi 2:1 şeklindedir. $\mathrm{Bu}$ nedenle yemlerde de aynı dengenin olması gerekir (Miller ve Retz, 1995). Ca/P oranı 2'nin üzerinde olan yemlerle özellikle sağmal hayvanlarda uzun süre besleme yapıldığında süt humması ortaya çıkmakta, yem tüketimi ve süt verimi azalmaktadır (Açıkgöz, 2001). Ancak, hayvanlar yeterince D vitamini aldıklarında bu oran 7:1'e kadar tolere edilebilmektedir (Buxton ve Fales, 1994; Mayland ve Hankins, 2001). OÜ genotiplerinde belirlenen oranlar diğer araştırıcıların bulguları ile uyumlu olmakla birlikte, hayvan besleme açısından tehlikeli olan sınıra yakındır.

Elde edilen sonuçların ışığı altında șu öneriler ortaya konulabilir.

Orman üçgülü genotipleri uygun seçim yapılmak koşuluyla, iklimin ılıman olduğu sahil bölgelerinde yil boyunca hayvanlara yeşil yem sağlama potansiyeli taşımaktadır. Sulama ve gübreleme yapılmadığı ve hiçbir hastalık ve zararlısının gözlenmediği dikkate alındığında, uygun çeşitler geliștirildiği zaman sulanamayan, düşük verimli alanlarda mera ve yem bitkisi olarak yetiştirilebilir. Mevsimsel dalgalanmalar olsa bile, yapraklarda ham protein oranı yüksek, ADF ve NDF oranı düşük olduğundan yem kalitesi çok yüksektir. Ancak, özellikle süt hayvanlarının beslenmesinde tek başına uzun süreli kullanımında dikkatli olunmalıdır. Aksi halde, yüksek $\mathrm{Ca} / \mathrm{P}$ oranı süt hummasına ve verim düşüklüğüne yol açabilir.

\section{Teşekkür}

Bu çalışma OMÜ BAP tarafindan PYO.ZRT.1904.15.009 proje numarası ile desteklenmiștir. Bazı veriler Elif Tuzen Şahin'in Yüksek Lisans Tezinden alınmıștır.

\section{Kaynaklar}

Acar, Z., Ayan, İ., \& Gülser, C. (2001). Some morphological and nutritional properties of legumes under natural conditions. Pakistan Journal of Biological Sciences, 4(11), 1312-1315.

Acar, Z., Kumbasar, F., Ayan, I., Can, M., Tuzen, E., Zeybek, S., \& Kaymak, G. (2016a). Effects of plant development phases on some morphological, agronomical and chemical traits of Bituminaria bituminosa genotypes. 15 th FAO-CIHEAM Mediterranean Grassland. 12-14 April, Orestiada, Greece.

Acar, Z., Kumbasar, F., Ayan, I., Can, M., Tuzen, E., Zeybek, S., \& Kaymak, G. (2016b). Is it possible to develop dormancy groups for Bituminaria bituminosa L. 15th FAOCIHEAM Mediterranean Grassland. 12-14 April, Orestiada, Greece.

Açıkgöz, E. (2001). Yem Bitkileri. Uludă̆ Üniversitesi. Güçlendirme Vakfı Yayın, Bursa No: 182.

AFGC (2009). Relative Feed Value. American Forage and Grassland Council. http://www.buckevenutrition .com /eQuinetechnical/EB22\%20RELATIVE\%20 FEED\%20V ALUE.pdf (13.04.2009).

Alvarez, S., Mendez, P., Diaz, C., \& Fresno, M. (2004). Ingestion, chemical composition and in vivo digestibility of tedera (Bituminaria bituminosa (L.) Stirton), In 'Reunión Científica de la Sociedad Española para el Estudio de los Pastos, 44., Salamanca (España), Salamanca 337-340 pp.

Buxton, D. R., \& Fales, S. L. (1994). Plant Environment and Quality. Forage Quality, Evaluation and Utilization (Eds. G.C. Fahey, : Collins, D.R. Mertens \& L.E. Moser), Madison, WI, USA. 155-199.

Elinç, F. (2007). Bitki besleme ve toprak verimliliği. Ondokuz Mayıs Üniversitesi, Ziraat Fakültesi Ders Kitabı, Samsun. No: (57) 1- 268 s.

FAO (2010). Bituminaria bituminosa C.H. Stirtion.http://www.fao.ory/ag/AGP/agpc/doc/Gb ase/new species/tedera/bitbit.htm.

Fernandez, D., Walker, D.J., Romero, P., \& Correal, E. (2010). The physiology of drought tolerance in Tedera (Bituminaria bituminosa). Options Méditerranéennes, 92, 155-159.

Gintzburger, G., \& Le Houerou, H.N. (2002). Useful plants for Mediterranean climate agriculture and rangeland: Problem and solution for Mediterranean Australia: A review Ecology and Survival of Perennial Legumes in Dry Mediterranean Areas, 15-34 pp. 
Gulumser, E., Basaran, U., Acar, Z., Ayan, I., \& Mut, H. (2010). Determination of some agronomic traits of Bituminaria bituminosa accessions collected from Black Sea Region. Option Méditerranéennes, A 92: 105-108.

Gutman, M., Perevolotsky, A., \& Sternberg, M. (2000). Grazing effects on a perennial legume, Bituminaria bituminosa (L) Stirton, in a Mediterranean rangeland. Cahiers Options Méditerranéennes, 45, 299-303.

Gülümser, E. (2011). Orta Karadeniz Bölgesi'nde doğal olarak yetișen Bituminaria bituminosa L. (Syn. Psoralea bituminosa L.) bitkisinin tanımlanması ve tarımsal özelliklerinin araştırılması. Ondokuz Mayıs Üniversitesi, Fen bilimleri Enstitüsü, Yüksek Lisans Tezi, $86 \mathrm{~s}$.

IPGRI (1990). Descriptors for perennial legume plants. International Plant Genetic Resource Institute, Rome, Italy.

Kidambi, S.P. Matches, A.G., \& Grigs, T.C. (1989). Variability for $\mathrm{Ca}, \mathrm{Mg}, \mathrm{K}, \mathrm{Cu}, \mathrm{Zn}$ and $\mathrm{K} /(\mathrm{Ca}+\mathrm{Mg})$ ratio 3 wheat grasses and on the southern sainfoin high plains. Rangeland Ecology \& Management/Journal of Range Management Archives, 42(4), 316-322.

Korkmaz, A., Gülser, C., Manga, İ., \& Sancak, C. (1993). Samsun yöresinde elde edilen otun mineral madde içeriğine ve kalitesine ekim sistemi ve biçim zamanlarının etkileri. Türk Tarım ve Ormancilık Dergisi, 17, 1069-1080.

Kumbasar, F. (2015). Gelișme Dönemlerine Göre Bituminaria bituminosa L. Genotiplerinde Verim ve Kalite Özelliklerinin Değişimi. Ondokuz Mayıs Üniversitesi Ziraat Fakültesi. Yüksek lisans Tezi. 95

Mayland, H. F., \& Hankins, J. L. (2001). Mineral Imbalances and Animal Health: A Management Puzzle. Antiquality Factors in Rangeland and Pastureland Forages. In: Launchhbaugh, K. (Ed.), Rangeland Ecology and Management University of Idaho, Moscow, 54-61 pp.

Miller, D. A., \& Retz, H. F. (1995). Forage fertilization, Forage Vol. I, An Introduction to Grassland Agriculture: 79-91 pp.

Önal Aşçı, Ö., \& Acar, Z. (2018). Kaba Yemlerde Kalite. TMMOB Ziraat Mühendisleri Odası Yayınları, 112.

Pecetti, L., Tava, A. Pagnotta, M.A., \& Russi, L. (2007). Variation in forage quality and chemical composition among Italian accessions of Bituminaria bituminosa (L.) Stirt. Journal of the Science of Food and Agriculture, 87(6), 985-991.

Real, D., Albersten, T., Snowball, R., Howieson, J., Revell, C., Ewıng, M., Correal, E., Méndez, P. \& Rios, S. (2008). Bituminaria bituminosa var. albomarginata (Lancelot trefoil), a novel perennial forage legume for low-rainfall Mediterranean environments in Western Australia. In: XXI International Grassland Congress and VIII International Rangeland Congress. Hohhot, P.R. China. Volume II. 452.

Real, D., Oldham, C.M., Nelson, M.N. Croser, J., Castello, M., Verbyla, A., Pradhan, A., Van Burgel, A., Mendez, P., Correal, E., Teakle, N.L., Revel, C.K., \& Ewing, M.A. (2014). Evaluation and breeding of tedera for Mediterranean climates in southern Australia. Crop and Pasture Science, 65(11), 1114-1131.

Sternberg, M., Gishri, N., \& Mabjeesh, S.J, (2006). Effects of grazing on Bituminaria bituminosa (L.) Stirton: a potential forage crop in Mediterranean grasslands. ournal of agronomy and crop science, 192(6), 399. 407.

Tejeda, R., Mcdowell, L.R., Martin, F.G., ve Concard, J.H. (1985). Mineral element analyses of various tropical forages $\S n$ Guattamala and their relationship to soil concentrations. Nutrition reports international. (8), 71.

Uğur, S. 2008. Küresel Isınma ve Tarıma Etkisi. Ondokuz Mayıs Üniversitesi, Fen Bilimleri Enstitüsü Yüksek Lisans Semineri.

Underwood, E.J., \& Suttle, N.F. (1999). The mineral nutrition of livestock, $3^{\text {rd }}$ Edition. Commonwealth Agricultural Bureau International Publishing, 614 p.

Ventura, M. R., Flores, M. P., \& Castanon, J. I. R. (1999). Nutritive value of forage shrubs: Bituminaria bituminosa, Acacia salicina and Medicago arborea. In 'Cahiers Options Mediterraneennes. (CIHEAM), 39, 171-173.

Ventura, M. R., Castanon, J. I. R., Pieltain, M.C., \& Flores, M.P. (2004). Nutritive value of forage shrubs: Bituminaria bituminosa, Rumex lunaria, Acacia salicina, Cassia sturtii and Adenocarpus foliosus. Small Ruminant Research, 52(1-2), 13-18.

Ventura, M.R., Castanon, J.I.R., \& Mendez, P. (2009). Effect of season on tedera (Bituminaria bituminosa) intake by goats. Animal Feed Science and Technology, 153(3-4), 314-319. 
Ward, G.M. (1966). Potassium metabolism of domestic ruminants: A review. Journal of Dairy Science, 49(3), 268-276.

Yavuz, M., İptaș, S., Ayhan, V., \& Karadağ, Y. (2009). Yembitkilerinde Kalite ve Yembitkilerinden
Kaynaklanan Beslenme Bozuklukları. Yembitkileri, Genel Bölüm (Editörler: Avcıoğlu R, Hatipoğlu R, Karadağ Y). Tarım ve Köyişleri Bakanlığı, Tarımsal Üretim ve Geliştirme Genel Müdürlügü, İzmir, Cilt I, 163-172. 